\title{
PELATIHAN PENCEGAHAN DAN PERAWATAN CIDERA DALAM BEROLAHRAGA
}

\author{
Ilham Arvan Junaidi ${ }^{1}$, Nasrullah ${ }^{2}$, Farizal Imansyah ${ }^{3}$, I Made Andika Bayu ${ }^{4}$, \\ Jujur Gunawan Manullang ${ }^{5}$, Widya Handayani ${ }^{6}$, Asriansyah ${ }^{7}$, Al Azis Hardi ${ }^{8}$ \\ Program Studi Pendidikan Olahraga Universitas PGRI Palembang \\ E-mail: arvan_coky@yahoo.com ${ }^{1}$, nasrullah1207@gmail.com², \\ farizalpklo@gmail.com ${ }^{3}$,imadebayuandika@gmail.com ${ }^{4}$,jujurgm@yahoo.co.id ${ }^{5}$, \\ wi_dya87@yahoo.co.id ${ }^{6}$, asriansyah_syah@yahoo.com ${ }^{7}$, alazishardi@gmail.com ${ }^{8}$
}

\begin{abstract}
Abstrak
Hasil dari kegiatan Sosialisasi berbasis sekolah ini adalah meningkatkan pengetahuan dan membuat para siswa memahami manfaat dari pencegahan dan perawatan cidera dalam berolahraga. Jadi, para siswa dapat mengetahui bagaimana pertolongan pertama dalam olahraga serta mengatasi cidera ketika berolahraga karena apabila tidak ditangani maka akan dapat menimbulkan resiko yang lebih fatal seperti cacat permanen dan kematian. Setelah sosialisasi, para siswa lebih percaya diri dalam melakukan aktifitas berolahraga bagi siswa SMK 5 Pangkal Pinang dan SMK Sore Pangkal Pinang.
\end{abstract}

\section{Kata Kunci: Pencegahan dan Perawatan Cidera dalam Berolahraga}

\begin{abstract}
The results of this school-based outreach activity are to increase knowledge and make students understand the benefits of prevention and treatment of injuries in sports. So, students can find out how first aid in sports and overcome injuries when exercising because if not handled it can lead to more fatal risks such as permanent disability and death. After the socialization, the students were more confident in doing sports activities for students of SMK 5 Pangkal Pinang and SMK Sore Pangkal Pinang.
\end{abstract}

\section{Kata Kunci: Prevention and Treatment of Injuries in Exercise}

\section{Pendahuluan}

Berdasarkan UU RI Nomor 20 tentang sistem pendidikan nasional dan PP RI Nomor 10 Tahun 1999 bahwa perguruan tinggi dapat menyelenggarakan pengabdian pada masyarakat sesuai dengan sifat pengetahuan dan tujuan pendidikan tinggi yang bersangkutan. Pengabdian pada masyarakat adalah kegiatan yang memanfaatkan ilmu pengetahuan dalam upaya memberikan sumbangan demi kemajuan masyarakat. Sekolah adalah salahsatu lembaga dalam mencapai tujuan pendidikan nasional. Penjaskes sebagai salah satu materi pembelajaran di sekolah memiliki tujuan, yaitu memberikan keterampilan gerak untuk peserta didik, dengan harapan keterampilan gerak yang sudah dimiliki untuk dapat dikembangkan dan ditingkatkan ke dalam pengembangan spesialisasi gerak cabang olahraga tertentu sesuai bakat, minat dan potensi yang 
dimiliki peserta didik. Tujuan tersebut tertuang dalam pasal 25 ayat 3 UU no. 3 tahun 2005 tentang Sistem Keolahragaan Nasional. Adapun isi dari pasal 25 ayat 3 adalah pembinaan dan pengembangan olahraga pendidikan pada semua jenjang pendidikan memberikan kebebasan kepada peserta didik untuk melakukan kegiatan olahraga sesuai dengan bakat dan minat.

Ruang lingkup mata pelajaran Penjasorkes pada jenjang SMA meliputi permainan dan olahraga, aktivitas pengembangan, aktivitas senam, aktivitas ritmik, aktivitas air, pendidikan luar kelas, dan kesehatan. Ruang lingkup permainan dan olahraga meliputi olahraga tradisional, permainan ekplorasi gerak, keterampilan lokomotor non-lokomotor, dan manipulatif, atletik, kasti, rounders, kippers, sepakbola, bolabasket, bolavoli, bolatangan, tenis meja, tenis lapangan, bulu tangkis, beladiri, serta aktivitas lainnya. Dalam melaksanakan kegiatan olahraga tersebut maka dibutuhkan kondisi fisik yang prima, terkadang dalam pelaksanaannya banyak terdapat hal-hal yang tidan diinginkan seperti cidera dalam berolahraga.

Cidera dalam olahraga merupakan halhal yang sangat dihindari oleh seorang pemain. Cedera olahraga sering terjadi pada cabang olahraga yang mempunyai intensitas tinggi dan kontak fisik. Apabila hal ini terjadi maka seorang pelatih maupun pemain harus bisa memberikan bantuan pertama dalam mengatasi hal tersebut karena apabila tidak ditangani maka akan dapat menimbulkan resiko yang lebih fatal seperti cacat permanen dan kematian. Jenis-jenis cidera yang sering ditemui dalam aktifitas belolahraga adalah seperti, keram, patah tulang, trauma (benturan), gegar otak, pingsan, dan sebagainya.

\section{Bahan dan Metode Pelaksanaan}

$$
\text { Kegiatan Pengabdian Kepada }
$$

Masyarakat (PKM) di SMK Negeri 5 Pangkal Pinang dilakukan pada hari Senin Tanggal 5 Februari 2018 di aula serbaguna yang ada pada sekolah tersebut. Sedangkan SMK Sore Pangkal Pinang dilakukan pada hari Selasa Tanggal 6 Februari 2018. Acara tersebut dimulai pada pukul 08:00 WIB diawali dengan menguraikan bahwa Pengabdian pada Masyarakat (PPM) ini merupakan salah satu dari tugas pokok Dosen (Tri Darma Perguruan Tinggi) yaitu Pengajaran, Pengabdian pada Masyarakat, dan Penelitian.

Kemudian dilanjutkan dengan dengan sambutan yang disampaikan oleh Kepala bidang Kesiswaan. Beliau menyampaikan terima kasih kepada pihak Universitas PGRI Palembang dan LPPKMK pada khususnya karena telah mempercayai SMKN 5 Pangkal Pinang dan SMK Sore Pangkal Pinang sebagai sekolah yang memfasilitasi Dosen di Universitas PGRI Palembang untuk mengadakan Pengabdian pada Masyarakat dimana kegiatan ini pertama kali dilakukan di luar Provinsi Sumatera Selatan, serta berharap juga bahwa hubungan baik yang selama ini sudah terjalin antara SMKN 5 Pangkal Pinang dan SMK Sore Pangkal Pinang.

Selanjutnya pukul 09:00-09:20 WIB dimulai dengan presentasi pertama yang disampaikan oleh Ilham Arvan Junaidi, M.Pd yang berjudul Pengantar Pencegahan dan Perawatan Cidera dalam Berolahraga. Pada pukul 09:30-10:00 WIB presentasi 
kedua disampaikan oleh Nasrullah, M.Pd yang berjudul Cara-cara Fisioterapi. Sesi ketiga dilanjutkan dengan pada pukul 10:0011:00 WIB disampaikan oleh Jujur Gunawan Manullang, M.Pd dan I Made Andika Bayu, M.Pd. yang bersangkutan menerangkan tentang Cara Mengatasi Dislokasi dan Patah Tulang.

Sesi keempat dilanjutkan dengan pada pukul 10:15-11:15 WIB disampaikan oleh Farizal Imansyah, M.Pd dan Widya Handyani, S.Pd, M.Si menjelaskan tentang Cidera di Dalam Air dan Cidera Umum. Dilanjutkan dengan sesi kelima pada pukul 12:15-13:15 WIB disampaikan oleh Al Azis Hardi, M.Pd dan Asriansyah, M.Or. Dalam sesi yang terakhir ini menerangkan tentang Cara Meminimalisir Terjadinya Cidera dan Benturan (trauma). Selanjutnya kegiatan ini ditutup dengan ucapan terima kasih dari pihak sekolah kemudian doa.

Alat-alat yang digunakan pada kegiatan ini adalah bidai, perban, taping, handuk dan massage oil. Pada akhir kegiatan ini, dilakukan tanya jawab. Pada sesi tanya jawab diberikan 10 pertanyaan mencakup tentang materi-materi yang telah diberikan pada sesi sebelumnya. Sesi tanya jawab ini kemudian hasilnya dijadikan sebagai evaluasi bahwa kegiatan ini untuk mengetahui tingkat pemahaman siswa.

\section{Hasil dan Pembahasan}

Proses kegiatan PKM berlangsung sesuai jadwal. Semua pihak yang telah berupaya sebaik mungkin sesuai kemampuan dan kondisi yang ada. Kegiatan ini dirasakan sangat perlu, namun diharapkan terdapat peningkatan dalam berbagai aspek sehingga pada kegiatan yang akan datang akan menjadi lebih baik.

Pada inti dari kegiatan ini, siswa diberikan pengarahan mengenai pencegahan dan perawatan cidera dalam berolahraga. yang dimulai dari pengantar pencegahan dan perawatan cidera dalam berolahraga kemudian cara-cara melakukan fisioterapi, mengatasi cidera ketika di dalam air, pertolongan pertama apabila patah tulang, mengatasi apabila terjadi dislokasi dan meminimalisir terjadinya cidera serta trauma (Hartono, 2002).

Pada tahap ini, siswa diminta untuk memperhatikan dengan cermat mengenai pemaparan yang disampaikan oleh pemateri. Siswa diberikan fotokopi materi agar memberikan kemudahan bagi siswa dalam menyimak pemateri.

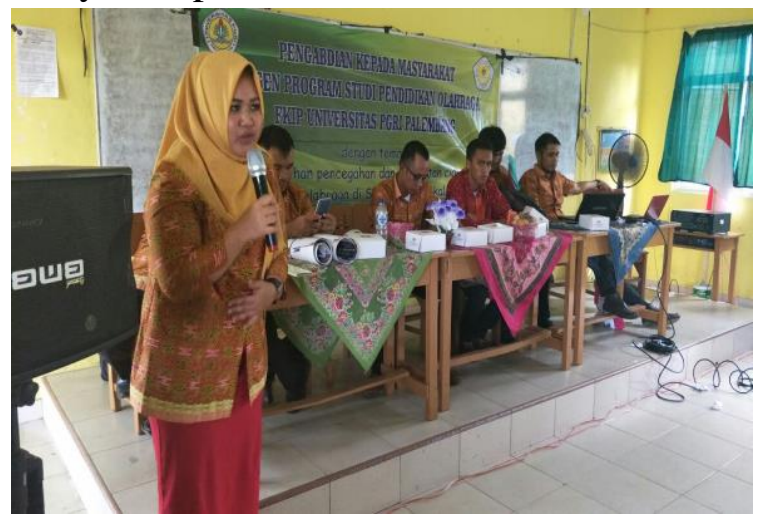

\section{Gambar 1. Pembukaan Materi Cidera}

Pada tahapan selanjutnya di kegiatan ini, siswa diberi kesempatan untuk melihat, mengamati dan mempraktikkan bagaimana cara mengatasi cidera dalam berolahraga terutama apabila terjadi patah tulang dan dislokasi (Rusli, 2001). 


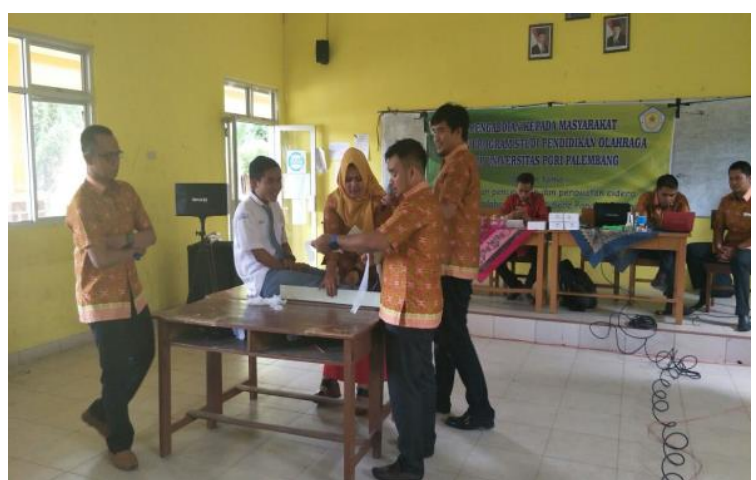

Gambar 2. Cara Pembidaian

Pada tahap selanjutnya, siswa dapat melihat cara melakukan massage. Siswa juga diminta untuk dapat ikut serta Selain itu, terjadinya trauma dalam beraktifitas.

Siswa juga diberi pengarahan bagaimana fase-fase dalam pemasangan taping serta menjelaskan tentang kinesio taping merupakan suatu materi sejenis lakban yang diciptakan menggunakan teknologi tinggi. Fungsi utama dari lakban ini adalah untuk memberikan elastisitas lebih kuat bagi otot-otot yang terasa kejang dan juga melindungi serta mendukung otot. Beberapa orang juga menggunakan lakban ini untuk mencegah kemungkinan terjadinya cedera karena kelelahan dan kejang pada otot (Ronald, 2009).

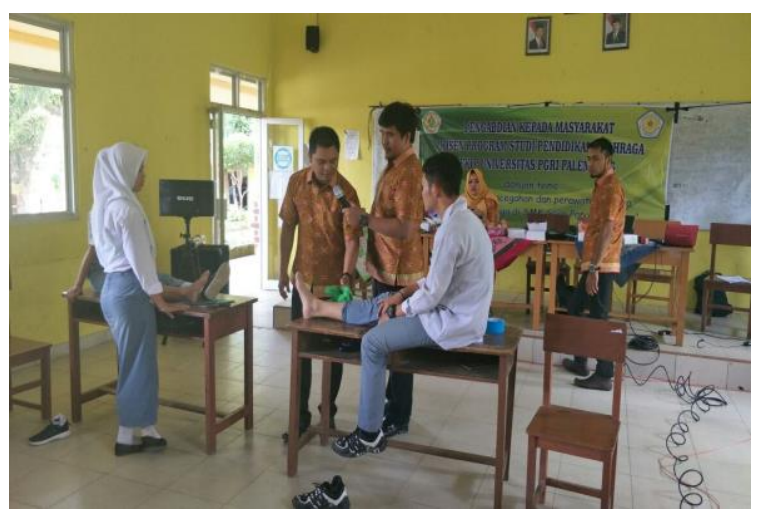

Gambar 2. Massage

Pencegahan merupakan suatu upaya yang dilakukan seseorang untuk menghambat sesuatu hal yang akan terjadi, pencegahan juga bisa diartikan sebagai penanggulangan atau tindakan yang dilakukan agar hal yang tidak diingin kan tidak terjadi atau mengurangi dampak sesuatu hal yang tidak diinginkann terjadi. Berdasarkan hasil tanya jawab kepada siswa selama kegiatan berlangsung, dapat diketahui bahwa masih belum mengetahui cara-cara mengatasinya.

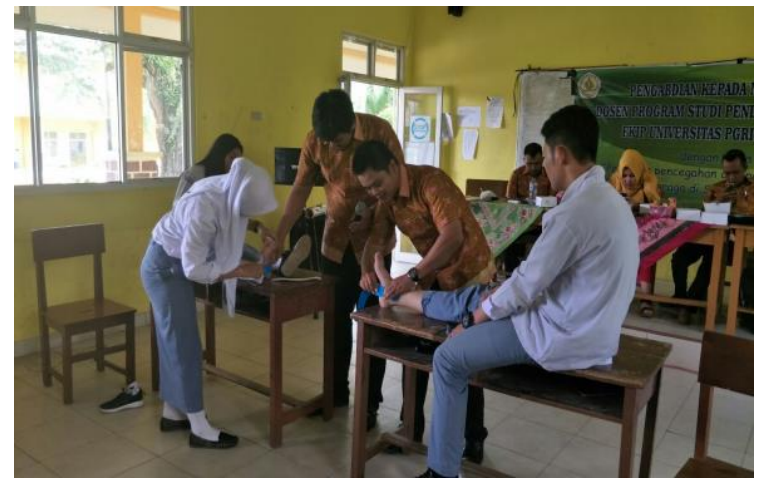

Gambar 4. Pemasangan Taping

\section{Simpulan}

Setelah diadakannya sosialisasi ini diharapkan para siswa dan guru mengetahui dan memahami pencegahan dalam Melakukan aktifitas olahraga. untuk memberikan pertolongan pertama pada kecelakaan di tempat kejadian dengan cepat dan tepat sebelum tenaga medis datang atau sebelum korban dibawa kerumah sakit agar kejadian yang lebih buruk dapat dihindari.Tujuannya adalah mencegah maut dan mempertahankan hidup, mencegah penurunan kondisi badan atau cacat.

Hasil akhir dari penyelenggaraan kegiatan PKM ini adalah bertambahnya pengetahuan dan pemahaman siswa dan dapat mengaplikasikan kedepannya sehingga siswa lebih percaya diri dalam melakukan aktifitas berolahraga dan menghasilkan 
prestasi yang membanggakan terhadap SMK

Negeri 5 Pangkal Pinang dan SMK Sore Pangkal Pinang.

\section{Daftar Pustaka}

Hartono, S. (2002). Pencegahan Cedera Olahraga. Jakarta: Erlangga.

Rusli, L. (2001). Penanggulangan Cedera Olahraga pada Anak Sekolah Dasar. Jakarta: Ditjen Olahraga.

Ronald. P. Feiffer. (2009). Sports First Aids (Pertolongan Pertama dan Ilmu Kedokteran Olahraga). Jakarta: Binarupa Aksar. 